\title{
Climate, soil or both? Which variables are better predictors of the distributions of Australian shrub species?
}

\author{
Yasmin Hageer $^{\text {Corresp.. }}{ }^{1}$ ， Manuel Esperón-Rodríguez ${ }^{1}$ ， John B Baumgartner ${ }^{1}$ ， Linda J Beaumont ${ }^{1}$ \\ ${ }^{1}$ Department of Biological Sciences, Macquarie University, Sydney, New South Wales, Australia \\ Corresponding Author: Yasmin Hageer \\ Email address: yasmin.hageer@gmail.com
}

Background: Shrubs play a key role in biogeochemical cycles, prevent soil and water erosion, provide forage for livestock, and are a source of food, wood and non-wood products. However, despite their ecological and societal importance, the influence of different environmental variables on shrub distributions remains unclear. We evaluated the influence of climate and soil characteristics, and whether including soil variables improved the performance of a species distribution model (SDM), Maxent.

Methods: This study assessed variation in predictions of environmental suitability for 29 Australian shrub species (representing dominant members of six shrubland classes) due to the use of alternative sets of predictor variables. Models were calibrated with 1) climate variables only, 2) climate and soil variables, and 3) soil variables only.

Results: The predictive power of SDMs differed substantially across species, but generally models calibrated with both climate and soil data performed better than those calibrated only with climate variables. Models calibrated solely with soil variables were the least accurate. We found regional differences in potential shrub species richness across Australia due to the use of different sets of variables.

Conclusions: Our study provides evidence that predicted patterns of species richness may be sensitive to the choice of predictor set when multiple, plausible alternatives exist, and demonstrates the importance of considering soil properties when modeling availability of habitat for plants. 
1 Title: Climate, soil or both? Which variables are better predictors of the

2 distributions of Australian shrub species?

3

4 Author names and addresses: Yasmin Hageer, Manuel Esperón-Rodríguez, John

5 B. Baumgartner \& Linda J. Beaumont

6

7 Hageer, Y. (yasmin.hageer@gmail.com) ${ }^{1}$

8 Esperón-Rodríguez, M. (manuel.esperon-rodriguez@mq.edu.au) ${ }^{1}$

9 Baumgartner, J. B. (john.baumgartner@mq.edu.au) ${ }^{1}$

10 Beaumont, L. J. (linda.beaumont@mq.edu.au) $)^{1}$

11

$12{ }^{1}$ Department of Biological Sciences, Macquarie University, NSW, 2109, Australia

13 Corresponding author: Yasmin Hageer

14 Email: Yasmin.hageer@gmail.com 


\section{Abstract}

17 Background: Shrubs play a key role in biogeochemical cycles, prevent soil and water erosion, provide forage for livestock, and are a source of food, wood and non-wood products. However, despite their ecological and societal importance, the influence of different environmental variables on shrub distributions remains unclear. We evaluated the influence of climate and soil characteristics, and whether including soil variables improved the performance of a species distribution model (SDM), Maxent.

Methods: This study assessed variation in predictions of environmental suitability for 29 Australian shrub species, representing dominant members of six shrubland classes, due to the use of alternative sets of predictor variables. Models were calibrated with 1) climate variables only, 2) climate and soil variables, and 3) soil variables only.

Results: The predictive power of SDMs differed substantially across species, but generally models calibrated with both climate and soil data performed better than those calibrated only with climate variables. Models calibrated solely with soil variables were the least accurate. We found regional differences in potential shrub species richness across Australia due to the use of

31 different sets of variables.

Conclusions: Our study provides evidence that predicted patterns of species richness may be sensitive to the choice of predictor set when multiple, plausible alternatives exist, and demonstrates the importance of considering soil properties when modeling availability of habitat for plants.

Nomenclature: Australian Plant Census 
40 Abbreviations: AUC $=$ Area Under the Receiver Operating Characteristic curve; BD = bulk

41 density; CLAY = percent clay content; $\mathrm{P}=$ total annual precipitation $(\mathrm{mm}) ; \mathrm{OC}=$ organic

42 carbon; PQcold = total precipitation of the coldest quarter $(\mathrm{mm}) ; \mathrm{PQwarm}=$ total precipitation of

43 the warmest quarter $(\mathrm{mm}) ; \mathrm{SD}=$ standard deviation; $\mathrm{SDM}=$ species distribution model; $\mathrm{T}=$

44 mean annual temperature $\left({ }^{\circ} \mathrm{C}\right)$; TSS $=$ True Skill Statistic; TMwarm $=$ maximum temperature of

45 the warmest month $\left({ }^{\circ} \mathrm{C}\right) ; \mathrm{V}_{\mathrm{C}}=$ climate-only variable set; $\mathrm{V}_{\mathrm{C}+\mathrm{S}}=$ climate-plus-soil variable set; $\mathrm{V}_{\mathrm{S}}$

$46=$ soil-only variable set.

47 
63 Species distribution models (SDMs) are tools used to assess the spatial distribution of potentially

64 suitable habitat for species, and to hypothesise how suitability is affected by environmental

65 change (Guisan \& Thuiller 2005). These tools generally correlate species' occurrence patterns

66 with environmental variables, which are frequently selected from a set of 19 'bioclimatic' indices

67 (Nix, 1986) available in WorldClim (Hijmans et al. 2005).

68 Although climate is recognized as a major factor controlling species' distributions

69 (Brown \& Gibson 1983; Woodward 1987), climate variables are unlikely to be the only relevant

70 predictors of habitat availability (Chatfield et al. 2010; Austin \& Van Niel 2011), as plant

71 survival and reproduction also depends on light, nutrients, water, and $\mathrm{CO}_{2}$, as well as

72 disturbances and biotic interactions (Hibbard 2001; Neher et al. 2004; Jackson 2009).

73 However, comparatively a few SDM studies directly incorporate non-climatic

74 environmental variables such as soil properties (but see Fitzpatrick et al. 2008; Martinson et al.

75 2011; Zhou et al. 2012; Condit et al. 2013; Taylor \& Kumar 2013), even though the soil

76 properties are known to considerably impacts the distribution of plant species (Elmendorf et al.

77 2008, Dubuis et al. 2013) for its importance to the plants as source of water and nutrients (Aerts

78 \& Chapin 2000) and physically for supporting root growth (Martre et al. 2002). Furthermore,

some studies incorporated other factors in SDMs such as irradiance (see Franklin 1998;

Summers et al. 2012) as a light source for the plants, topography (Franklin 1998; Hosseini et al.

81 2013), and landuse (Meier et al. 2012; Stanton et al. 2012; Titeux et al. 2016) in which

82 degradation in plant habitats and loss of plant biodiversity is strongly influenced by changes in

83 landuse and increase of urbanization is considered (Lawler et al. 2014). This poorly integration

84 of non-climatic factors in modelling studies may partly reflect difficulties with obtaining

85 appropriate data sets at relevant spatial scales, particularly with regards to soil variables that are 
86 related to plant functionality. It is highly recommended by all these modelling studies that SDMs

87 should be calibrated with physiologically-relevant environmental variables, as this should lead to

88

89

90

91

92

93

94

95

96

97

SDMs with greater predictive power (Austin 2002, 2007; Williams et al. 2012).

Whilst not a strict botanical category, shrubs are generally regarded as low height, woody perennial plants with several base-stems (Zeng et al. 2008; Meng et al. 2009). As the dominant flora in arid and semi-arid regions, shrubs play a key role in enhancing soil fertility, reducing runoff, soil loss (Pressland 1973; Xu et al. 2008; Song et al. 2013) and dust emissions (Engelstaedter 2003), and sequestering carbon in grassland ecosystems (Yashiro et al. 2010). By providing fodder for livestock (Lefroy et al. 1992), shrubs can enhance economic returns for dryland farms by providing an ‘out-of-season' food source (Monjardino et al. 2010).

The distribution of shrub species is strongly influenced by environmental conditions, such as climate (Pedley 1979; Westman 1991; Kienast et al. 1998). Plant species occurring in arid to semi-arid regions have evolved several traits enabling them to tolerate extended periods of low precipitation and high temperature. These include small leaves (Smith et al. 1997), slower growth rates, and more horizontal, rather than vertical, growth (Zeng et al. 2008). During the hot and dry season, stomata may be partly closed, reducing transpiration and water loss, leaves may be shed (Smith et al. 1997), and physiological activity is restricted (Reynolds 1999). Following rainfall events, leaves expand and stomata fully open (Zeng et al. 2008), and the negative impacts of the dry season may be compensated for via enhanced physiology and growth (Reynolds 1999). Shrubs also have a deeper, wider rooting system than grasses, enabling the efficient extraction of water in low moisture environments (Burgess 1995).

Physical and chemical soil properties, and biotic interactions play a major role in controlling the distribution of shrub species (Pedley 1979). Shrubs usually occur on shallow, 
109 coarse and infertile soils (Groves 1994), and are adapted to live on sandy soils with limited

110 moisture. Shrubs often accumulate their organic matter beneath their canopies, thereby enriching

111 the nutrient pool horizontally, enabling these species to grow in infertile soils (Zinke 1962;

112 Jackson \& Caldwell 1993; Schlesinger et al. 1996; Burke et al. 1998) and providing

113 microclimatic conditions that stimulate microbial biomass and activity (Sandoval Perez et al.

114 2016).

115 In this study, we assessed the extent to which soil variables, in conjunction with climate,

116 may increase the predictive power of habitat suitability models of Australian shrub species. We

117 hypothesised that models calibrated with both climate variables and soil properties will have

118 greater predictive power compared with models that incorporate only climate or soil parameters.

119 To test this hypothesis, we selected as a case study 29 shrub species that together span the

120 distribution of major shrubland vegetation types across the continent.

121

122

\section{Methods}

\subsection{Species data}

124 Shrubs are recognized as plants that are woody, "multi-stemmed at the base (or within $200 \mathrm{~mm}$

125 from ground level) or single stemmed, and less than $2 \mathrm{~m}$ ” in height (ESCAVI 2003, p. 87).

126 Species are grouped into five growth forms: acacia, mallee (Eucalypt species), heath (which

127 typically belong to Epacridaceae, Myrtaceae, Fabaceae and Proteaceae), chenopods, and

128 samphire. Combined, these five shrub growth forms occupy a substantial part of the Australian

129 landmass, mainly in semi-arid and arid regions, which form ca. $70 \%$ of the continent.

130 We identified 29 shrub species for inclusion in this study (Table 1), based on their

131 dominance and endemism. Combined, these species represent the variety of shrub growth forms 
132 present on the continent. We obtained occurrence records from the Atlas of Living Australia

133 (ALA, see http://www.ala.org.au/). Prior to downloading records, we applied filters to exclude

134 records that did not contain coordinates (an average of $2 \%$ of records per species), were collected

135 before 1960, or were identified by ALA as environmental outliers given the climatic envelope of

136 the species. This resulted in an average of 3,523 $(\mathrm{SD}=3,214)$ records per species.

137

\subsection{Selection of predictor variables}

139 We considered annual, seasonal and monthly climate variables known to influence the

140 distribution of shrubs (e.g. Xin-Rong 2001; Li et al. 2009; Gheradi \& Sala 2015). Gridded data

141 for nineteen climate variables, developed by the Wallace Initiative (http://wallaceinitiative.org),

142 were downloaded at a resolution of $0.05 \times 0.05$ arc-minutes. These data were derived from

143 spatially interpolated monthly precipitation and temperature observations (baseline period 1976-

144 2005) obtained from the Australian Water Availability Project (AWAP, Raupach et al. 2009,

145 Raupach et al. 2012; http://www.bom.gov.au/jsp/awap/) (for more details see VanDerWal et al.

146 2011). Multicollinearity of variables can result in over-fitting of SDMs and complicate

147 interpretation of variables' contributions (Elith et al. 2010; Williams et al. 2012; Zhou et al.

148 2012), therefore we assessed pair-wise correlations among variables. When Pearson's correlation

149 coefficients were greater than 0.85 we removed one of the variables. This reduced the number of

150 climate variables to a set of five: Mean Annual Temperature (T), Maximum Temperature of the

151 Warmest Month (TMwarm), Total Annual Precipitation (P), Precipitation of the Warmest Quarter

152 (PQwarm), and Precipitation of the Coldest Quarter (PQcold). See correlation matrix of the

153 variables in Table S1.

154 Spatial data describing four soil variables that capture soil functionality (Sauer et al. 
155 2006; Fisher et al. 2011; Meier et al. 2012) were obtained from the CSIRO Data Access Portal at

156 a resolution of $3 \times 3$ arc-seconds $(\sim 90 \times 90 \mathrm{~m})$

157 (http://www.clw.csiro.au/aclep/soilandlandscapegrid/index.html). This data include: percent clay

158 content (CLAY; Viscarra Rossel et al. 2014a); bulk density (BD; Viscarra Rossel et al. 2014b),

159 which reflects soil porosity; $\mathrm{pH} \mathrm{CaCl}_{2}(\mathrm{pH}$; Viscarra Rossel et al. 2014c), which reflects soil

160 acidity; and organic carbon (OC; Viscarra Rossel et al. 2014d). These variables describe the

161 corresponding physical and chemical soil characteristics that are known to influence vascular

162 plant growth and distribution (e.g. Jarvis 1974; Crawley, 1997), and do not correlate highly to

163 each other (Table S1). For each soil variable used in this study, the three soil depth layers $(0-5$

$164 \mathrm{~cm} ; 5-15 \mathrm{~cm} ; 15-30 \mathrm{~cm})$ were highly correlated $(|\mathrm{r}|>0.98)$, thus, we used measurements from

165 the first layer only. Using ArcGIS v10.4 (ESRI Inc., 2010), all soil data were resampled to a

166 resolution of $0.05 \times 0.05$ arc-minutes using bilinear interpolation, thereby matching the

167 resolution of the climate data. Finally, each predictor variable was projected to a $5 \times 5 \mathrm{~km}$ equal

168 area grid (Australian Albers, EPSG: 3577).

169

170

\subsection{Generating Maxent models of shrub species' distributions}

171 Three sets of models were calibrated for each species. Models referred to as $\mathrm{V}_{\mathrm{C}+\mathrm{S}}$ were calibrated

172 with climate and soil variables, $\mathrm{V}_{\mathrm{C}}$ models were calibrated with climate variables only, and $\mathrm{V}_{\mathrm{S}}$

173 models used only soil variables (Table 2).

174

We used Maxent (version 3.3.3k; Phillips et al. 2004, 2006) to develop SDMs for all 29

175 species. Maxent is a presence-only modelling approach that produces a continuous probability

176 field that can be interpreted as a relative index of environmental suitability. Higher values

177 represent greater suitability of a region for the target species (Phillips et al. 2004, 2006). A more 
178 detailed description of Maxent can be found in Elith et al. (2011).

179 Models were initially fit using default settings. We then explored how different

180 mathematical transformations of predictor variables ("features") influenced model predictions,

181 and concluded that superior models were obtained when linear, quadratic, and product features

182 were used. For each species, we generated a unique set of background points by identifying the

183 subset of biogeographic subregion polygons (IBRA, 2015 version 7.0) that contained occurrence

184 points for the species, and randomly selecting up to 10,000 occurrence records from all plant

185 records that fell within that subset of polygons (i.e., a spatially-constrained target-group

186 background sample). This approach aims to balance environmental sampling biases between the

187 modelled species and the background records required by Maxent for model calibration (Warren

188 et al. 2008; Phillips et al. 2009; Merow et al. 2013).

189 To reduce bias caused by randomly selecting occurrence records for model training, we

190 generated five cross-validated replicate models for each species, using a different subset of $20 \%$

191 of occurrence records to test each model. For each species, the five replicate models were

192 projected to the model-fitting predictor grids, and these five projections were then averaged to

193 produce the final projection.

\subsection{Model performance}

196 Currently, there is no ideal approach for evaluating model performance, although the area under

197 the receiver-operating characteristic curve (AUC) is the most common measure of the performance of Maxent (Merow et al. 2013). A high AUC score indicates that the model can distinguish between presence and background points, with model performance generally

200 considered good when AUC > 0.75 (Pearce \& Ferrier 2000; Elith et al. 2006). Here, we used 
201 AUC as an indicator of model performance when models were calibrated with different sets of

202 environmental factors. For each species we calculated the average test AUC over cross-

203 validation replicates for each candidate model $\left(V_{C}, V_{S}, V_{C+S}\right)$. We then identified which of the

204 models led to the highest AUC. To test whether increasing number of variables in the $\mathrm{V}_{\mathrm{C}+\mathrm{S}}$

205 would affect the value of AUC compared to the other models $\left(\mathrm{V}_{\mathrm{C}}, \mathrm{V}_{\mathrm{S}}\right)$, we computed the number

206 of parameters used in each fitted model using lambdas file corresponds to the number of features

207 in the model and correlated the number of parameters with AUC score for each species in the

208 model. In addition, for each model we calculated the maximum value of the True Skill Statistic

209 (TSS) on test data. Unlike AUC, which is threshold-independent, TSS reflects a model's

210 sensitivity and specificity at a particular threshold. As such, it was proposed as an appropriate

211 measure of model performance when the modelling application requires dichotomous maps of

212 habitat suitability (Allouche et al. 2006). TSS values range from -1 to 1 , where 1 implies perfect

213 sensitivity and specificity, and values of zero or less indicate considerable commission and/or

214 omission errors.

\subsection{Statistical analyses}

217 Maxent suitability scores were converted to binary suitability (suitable/unsuitable) using the

218 maximum training sensitivity plus specificity threshold (as recommended by Liu et al. 2013),

219 which is numerically equivalent to the threshold corresponding to the maximum TSS. We then

220 calculated pair-wise differences in the total area of suitable habitat predicted by the three sets of

221 Maxent models using the ArcGIS extension SDMtoolbox (Brown 2014). We also calculated

222 potential shrub species 'richness', i.e. the number of species for which a grid cell was classified

223 as suitable. These are not maps of species richness per se, rather they are estimates of how many 
224 of the 29 species a given grid cell may be suitable for.

225

226

227

228

229

230

231

232

233

234

235

236

237

238

239

240

241

242

243

244

\section{Results}

\subsection{Model Performance}

Of the 29 species, $\mathrm{V}_{\mathrm{C}+\mathrm{S}}$ models had the highest mean AUC and TSS for 27 and 25 species, respectively (Fig. 1). Across all species, AUC was, on average, $0.848(\mathrm{SD}=0.0139), 0.823$ (0.0137), and $0.773(0.0187)$ for $\mathrm{V}_{\mathrm{C}+\mathrm{S}}, \mathrm{V}_{\mathrm{C}}$ and $\mathrm{V}_{\mathrm{S}}$ models, respectively, while the equivalent values for TSS were $0.583(0.100), 0.546(0.111)$, and $0.458(0.010)$. Among all species, AUC showed a weak relationship with number of environmental variables used in each model, correlation coefficients $|r|<0.26$ for each of $\mathrm{V}_{\mathrm{C}+\mathrm{S}}, \mathrm{V}_{\mathrm{C}}$ and $<0.20$ for $\mathrm{V}_{\mathrm{S}}$. Visual inspection of maps generated by Maxent indicated that $\mathrm{V}_{\mathrm{C}+\mathrm{S}}$ and $\mathrm{V}_{\mathrm{C}}$ models resulted in more realistic projections of habitat suitability than those calibrated with only soil variables (Fig. 2). However, $\mathrm{V}_{\mathrm{C}}$ models over-predicted the realized distribution for some species, whereas $\mathrm{V}_{\mathrm{C}+\mathrm{S}}$ models provided a closer approximation (e.g. Acacia victoriae and Eucalyptus spp., Fig. 2).

The area of suitable habitat projected by $\mathrm{V}_{\mathrm{C}+\mathrm{S}}$ models ranged from $72,442 \mathrm{~km}^{2}$ (Leptospermum scoparium) to $3,736,940 \mathrm{~km}^{2}$ (Atalaya hemiglauca). $\mathrm{V}_{\mathrm{C}}$ models projected suitable habitat ranging in area from $73,399 \mathrm{~km}^{2}$ (L. scoparium) to 5,463,020 $\mathrm{km}^{2}(A$. hemiglauca) (Table 1). Maps from $\mathrm{V}_{\mathrm{C}+\mathrm{S}}$ and $\mathrm{V}_{\mathrm{C}}$ models were similar for most species. Exceptions were A. victoriae, Atriplex eardleyae, Eucalyptus gracilis, Leptospermum continentale, and Maireana aphylla (Fig. 2). In contrast, projections from $\mathrm{V}_{\mathrm{S}}$ models tended to cover a smaller spatial extent and had greater fragmentation of suitable habitat.

At a continental scale, the three alternate sets of variables used for model calibration resulted in different patterns of potential richness for the 29 species (Fig. 3). Highest potential 
247 richness was associated with $\mathrm{V}_{\mathrm{S}}$ models, which predicted a total area of $\sim 135,000 \mathrm{~km}^{2}$ to be

248 suitable for at least 11 (maximum $=18$ ) of the 29 species. However, this map also showed

249 substantial spatial discontinuities (i.e. contiguous areas of high potential richness were smaller

250 than when using other predictor sets). In contrast, $\mathrm{V}_{\mathrm{C}+\mathrm{S}}$ models projected only $\sim 50,000 \mathrm{~km}^{2}$ to be

251 suitable for at least 11 (maximum $=15)$ species. Although broadly similar patterns were

252 projected by both $\mathrm{V}_{\mathrm{C}}$ and $\mathrm{V}_{\mathrm{C}+\mathrm{S}}$ models, the potential richness of shrub species was higher based 253 on $\mathrm{V}_{\mathrm{C}}$ models, particularly in central South Australia (Fig. 3).

\subsection{Contribution of climate and soil variables to models of shrub distributions}

In total, climate variables contributed more to $\mathrm{V}_{\mathrm{C}+\mathrm{S}}$ models than did soil variables for 20 of the

29 species (Table 3). The total contribution of climate variables in $\mathrm{V}_{\mathrm{C}+\mathrm{S}}$ models exceeded $80 \%$

for nine species (maximum $=98 \%$, Leptospermum lanigerum) and was $<20 \%$ for one species exceeded $80 \%$ for one species (E. gracilis) and was $<20 \%$ for nine species. Of the individual climate and soil variables, TMwarm and $\mathrm{pH}$ were the most influential for ten and eight species, respectively; however, OC contributed the least for 11 species including Atriplex and Eucalyptus species (Table 3).

For $\mathrm{V}_{\mathrm{C}}$ models, TMwarm and $\mathrm{T}$ were the most important variables for 14 and 10 species respectively, whereas $\mathrm{P}$ contributed the most for five species (Table 3). For models calibrated with soil variables only $\left(\mathrm{V}_{\mathrm{S}}\right), \mathrm{pH}$ and $\mathrm{BD}$ were the most important variables for 17 and eight species (maximum $86.7 \%$ E. gracilis and 69.7\% L. lanigerum), respectively, while OC contributed $>74 \%$ to the model for Allocasuarina campestris and BD contributed $39.2 \%$ to the model for L. continentale. 
271

272

273

274

275

276

277

278

279

280

281

282

283

284

285

286

287

288

289

290

291

292

293

\section{Discussion}

Species distribution models are frequently calibrated only with climate variables, but for plant species, does the addition of soil properties as predictors improve model performance? For 29 Australian shrub species, we found that: a) on average, models calibrated with both climate and soil variables $\left(\mathrm{V}_{\mathrm{C}+\mathrm{S}}\right)$ performed better than those calibrated solely with climate variables $\left(\mathrm{V}_{\mathrm{C}}\right)$ (Fig. 1); b) maximum temperature of the warmest month and $\mathrm{pH}$ were the most important contributors to $\mathrm{V}_{\mathrm{C}+\mathrm{S}}$ models for ten and eight species, respectively (Table 3); and c) models calibrated with only soil variables $\left(\mathrm{V}_{\mathrm{S}}\right)$ had lower AUC and TSS scores, indicating lower classification accuracy than $\mathrm{V}_{\mathrm{C}}$ models (Fig. 1), and frequently generated unrealistic predictions (Fig. $2 \& 3$ ). For some species the inclusion of soil properties along with climate variables resulted in projections of current habitat that more closely approximated the realized distribution, compared to models calibrated with climate variables only. As a consequence, although broadly similar patterns of potential species richness occurred at the regional level, at finer spatial scales these patterns diverged substantially, particularly in central South Australia (Fig. 3). To date, few studies have explicitly assessed whether the inclusion of soil variables increases the predictive power of SDMs, although a number of studies have included these as variables in model calibration (e.g. Condit et al. 2013; Fitzpatrick et al. 2008; Martinson et al. 2011; Taylor \& Kumar 2013; Zhou et al. 2012). By themselves, the soil variables included in this study did not result in biologically realistic maps of the realised distribution of the 29 shrub species. The distributions of suitable habitat predicted by these models were frequently fragmented or had abrupt boundaries inconsistent with the known distributions of populations (Fig. 3). Topography and soil type, for instance, are important in determining the suitability of habitat for fire-prone chaparral species in California (Franklin et al. 2000; Meentemeyer et al. 2001). In Australia, Bui 
294 et al. (2014) found that although climate has higher impact on controlling the distribution of

295 Acacia species at a continental scale, physical and chemical properties of soil were more useful

296 in explaining the distribution of shrub species in southern Australia.

297 At the scale of this study, models indicate that climate plays a greater role than soil

298 characteristics in defining the distribution of most of the 29 shrub species, although soil $\mathrm{pH}$ was

299 the key determinant for Eucalyptus species. Bui et al. (2017) found that incorporating soil

300 variables with climate was efficient for defining the distribution of Eucalyptus species and

301 strongly influenced some specific species in taxonomic sections (e.g. Aromatica and Dumaria),

302 although that climate was more important factor. These results are similar to Martinson et al.

303 (2011), who used Maxent to model the distributions of 30 species, including shrubs, across arid

304 areas of North America using climate and soil variables. Temperature variables, mainly T,

305 contributed the most to their models, and none of the three soil variables $(\mathrm{pH}$, clay concentration,

306 and total organic carbon) was the most important for any species. Variables, such as cation

307 exchange capacity and texture, also contributed little to models predicting the distributions of

308 European trees (Meier et al. 2012).

309 However, soil variables made a substantial contribution to $\mathrm{V}_{\mathrm{C}+\mathrm{S}}$ models for some species.

310 For instance, among Eucalyptus species, $\mathrm{pH}$ was the highest contributing variable in $\mathrm{V}_{\mathrm{C}+\mathrm{S}}$

311 models. Eucalypts are adapted to live in acidic soils ranging from pH 3.5 to 6 (Evans 1992),

312 through a symbiotic relationship with ectomycorrhizal fungi (Malajczuk et al. 1975). Conversely,

313 growth of Acacia shrubs is restricted in high $\mathrm{pH}$ soils due to reductions in nutrient availability

314 (Nano \& Clarke 2008). Again, pH contributed highly to $\mathrm{V}_{\mathrm{C}+\mathrm{S}}$ models for several Acacia species.

315 Soil bulk density contributed the most to the $\mathrm{V}_{\mathrm{C}+\mathrm{S}}$ model for the saltbush Atriplex nummularia,

316 which is known to favour heavy clay soils (Cunningham et al. 1992). Clay soils are found to 
317 have lower cation exchange from the organic matter than sandy soil (McDonald, et al 2017). This

318 may explain the low contribution of soil organic carbon in the models for Atriplex species. These

319 findings highlight the importance of knowledge about specific characteristic and biological

320 idiosyncrasies that species possess to include them as variables predictors.

321 González-Orozco et al. (2013) found annual precipitation and percentage of sand in the

322 topsoil to be key environmental factors influencing the distribution of Australian Acacia species.

323 Our results support this, with precipitation contributing the most to $\mathrm{V}_{\mathrm{C}+\mathrm{S}}$ model for $A$. aneura and

324 A. tetragonophylla, while bulk density was also important.

325

326

327

328

329

330

331

332

333

334

335

336

337

338

339

\section{Caveats}

The accuracy of SDMs is influenced by a number of factors, including accuracy and availability of environmental data used to calibrate models (Buisson et al. 2010), biases in occurrence records (Liu et al. 2009), and the selection of model parameters (Beaumont et al. 2008).

Environmental data frequently require manipulation before use in SDMs, and this often involves resampling data to different resolutions. Aggregation or interpolation to a coarser or finer resolution, respectively, can alter the accuracy of data. In order to match the spatial resolution of the climate data, the soil dataset used in this study was aggregated from $90 \mathrm{~m}$ to 5 $\mathrm{km}$. Inconsistencies may have been magnified when the soil data were aggregated to a coarser resolution, and are apparent in some of the maps of suitable habitat. Interpolation and accuracy issues may also arise with climate data. For instance, although new high-resolution climate data $(1 \mathrm{~km})$ have recently become available (i.e., eMAST data products; http://www.emast.org.au/), precipitation-related variables may suffer accuracy problems when interpolating to areas with complex topography (Hutchinson 1995). We point out that SDMs calibrated with climate and 
340 soil datasets that more closely align in spatial resolution may have different findings to our study.

341 This remains an area requiring further exploration.

342 It is also likely that patterns in climate and soil do not influence species' distributions at

343 the same spatial scale. For example, different mallee species (Eucalyptus) in Western Australia

344 broadly occupy the same hot, dry climatic conditions. Within these climate zones, soil varies at a

345 finer scale. As such, E. diversifolia is restricted to the limestone coastal dunes and cliffs, while $E$.

346 incrassata occurs on sand plains such as in South Australia (Specht 1966). Therefore, trade-offs

347 will occur when selecting the most appropriate spatial scale and environmental variables for

348 modelling studies (Guisan \& Zimmermann 2000).

349 An additional hindrance might be the availability of environmental variables that used as

350 predictors in the models. For example, soil temperature and available water capacity of soil that

351 can be absorbed by roots, are suggested to be an important factors that potentially influence plant

352 growth (Dunne, 1996; Reddell et al. 1985) and could be incorporated in the SDMs. However,

353 lack of data of these variables at continental scale can be a challenge for using such variables in

354 modelling studies. Furthermore, for some studies that predictions of a variable under alternative

355 scenarios, such as climate change, may be required. Yet, these can be difficult to obtain. For

356 instance, while climate change projections for the standard 19 bioclimatic variables included in

357 WorldClim (Hijmans et al. 2005) and similar products are readily available, they may not be

358 available for other climate variables.

Accuracy of occurrence records and sampling biases associated with them may affect

SDM performance (Hefley et al. 2013). Sampling across arid and semi-arid zones of Australia has typically been poor and much clumped in space and time (Haque et al. 2017In press). Thus,

362 to reduce the likelihood of errors we applied filters to ALA records to exclude outliers. We 
363 decrease sampling bias by removing duplicate records in grid cells and adopted a target-group

364 background approach. Additionally, although we selected dominant, easily-identified species for

365 this study, it is not possible to determine whether their entire realized distribution (and hence,

366 climate envelope) has been sampled.

367 Regarding species richness, this is a convenient way to describe and compare the

368 biodiversity of different areas; however, there are concerns about over-estimating species

369 richness using combined or so-called stacked SDMs (Guisan \& Rahbek 2011; Hortal et al. 2012).

370 It is suggested that bias may be corrected by linking stacked SDMs to macroecological models;

371 nevertheless, early comparisons indicate that this approach has not yielded much improvement in

372 reducing overestimates of richness (Calabrese et al. 2014). The issue of how best to estimate

373 richness from stacked SDMs will undoubtedly be a key area of research over the next few years.

374

375 6. Conclusions

376 We demonstrate that for most of the shrub species modelled in this study, the inclusion of soil

377 properties, along with climate, resulted in more realistic predictions of the distribution of current

378 habitat. We also demonstrate how maps of suitable habitat can differ substantially depending on

379 whether models are calibrated with only climate variables or with climate and soil variables (e.g.

380 A. eardleyae and E. gracilis), even when AUC and TSS scores are very similar. This emphasises

381 the importance of interactive validation of model predictions, rather than relying solely on

382 popular metrics for assessing their accuracy. Furthermore, a promising recent application of

383 SDMs is to connect them with stochastic population models to estimate extinction risk (Keith et

384 al., 2008; Stanton et al., 2012). Such estimates are dependent on reasonable predictions of

385 suitable habitat as a function of climate conditions and other parameters such as soil type. This is 
386 an important consideration when applying SDM methods to scenarios of temporal environmental

387 change (e.g., climate change), whereby projections may continue to diverge. Our analysis

388 validates the approach of incorporating soil variables into SDMs, and we recommend that future

389 studies explore the contribution of soil variables when modelling the distributions of plant

390 species.

391

392 Acknowledgments

393 We thank Jeremy VanDerWal for assistance with climate data.

395 Conflict of interest

396 The authors declare that they have no conflicts of interest.

397

398

399

400

401

402

403

404

405

406

407

References

408

409 Aerts, R, and Chapin, FS. 2000. The mineral nutrition of wild plants revisited: a re-evaluation of 410 processes and patterns. Advances in Ecological Research 30:1-67. 
411

412

413

414

415

416

417

418

419

420

421

422

423

424

425

426

427

428

429

430

431

432

433

434

435

436

437

438

439

440

441

442

443

444

445

446

447

448

449

450

451

452

453

454

455

456

457

458

459

460

Allouche O, Tsoar A, and Kadmon R. 2006. Assessing the accuracy of species distribution models: prevalence, kappa and the true skill statistic (TSS). Journal of Applied Ecology 43:1223-1232.

Austin M. 2002. Spatial prediction of species distribution: an interface between ecological theory and statistical modelling. Ecological Modelling 157:101-118.

Austin M. 2007. Species distribution models and ecological theory: a critical assessment and some possible new approaches. Ecological Modelling 200:1-19.

Austin MP, and Van Niel KP. 2011. Impact of landscape predictors on climate change modelling of species distributions: a case study with Eucalyptus fastigata in southern New South Wales, Australia. Journal of Biogeography 38:9-19.

Beaumont LJ, Hughes L, and Pitman A. 2008. Why is the choice of future climate scenarios for species distribution modelling important? Ecology Letters 11:1135-1146.

Brown JH, and Gibson AC. 1983. Biogeography: Mosby, St. Louis, Missouri.

Brown JL. 2014. SDMtoolbox: a python-based GIS toolkit for landscape genetic, biogeographic and species distribution model analyses. Methods in Ecology and Evolution 5:694-700.

Bui EN, Carlos E, González-Orozco CE, Miller JT. 2014. Acacia, climate, and geochemistry in Australia. Plant and Soil 381:161-175.

Bui EN, Thornhill AH, González-Orozco CE, Knerr N, Miller JT. 2017. Climate and geochemistry as drivers of eucalypt diversification in Australia. Geobiology.15:427-440.

Buisson L, Thuiller W, Casajus N, Lek S, and Grenouillet G. 2010. Uncertainty in ensemble forecasting of species distribution. Global Change Biology 16:1145-1157.

Burgess TL, McClaran M, and Van Devender T. 1995. Desert grassland, mixed shrub savanna, shrub steppe, or semidesert scrub. The Desert Grassland 31-67.

Burke IC, Lauenroth WK, Vinton MA, Hook PB, Kelly RH, Epstein HE, Aguiar MR, Robles MD, Aguilera MO, and Murphy KL. 1998. Plant-soil interactions in temperate grasslands. Plantinduced soil changes: Processes and feedbacks: Springer 121-143.

Calabrese JM, Certain G, Kraan C, and Dormann CF. 2014. Stacking species distribution models and adjusting bias by linking them to macroecological models. Global Ecology and Biogeography 23:99-112.

Chatfield BS, Van Niel KP, Kendrick GA, and Harvey ES. 2010. Combining environmental gradients to explain and predict the structure of demersal fish distributions. Journal of Biogeography 37:593605.

Condit R, Engelbrecht BM, Pino D, Pérez R, and Turner BL. 2013. Species distributions in response to individual soil nutrients and seasonal drought across a community of tropical trees. Proceedings of the National Academy of Sciences 110:5064-5068.

Crawley MJ. 1997. Plant Ecology. Blackwell Science, Cambridge 70,357.

Cunningham G, Mulham W, Milthorpe P, and Leigh J. 1992. Plants of Western New South Wales., Inkata Press.

Dubuis A, Giovanettina S, Pellissier L, Pottier J, Vittoz P, Guisan A. Improving the prediction of plant species distribution and community composition by adding edaphic to topo-climatic variables. 2013. Journal of Vegetation Science 24:593-606.

Dunne KA. Global distribution of plant extractable-water capacity of soil. 1996. International Journal of Climatology.16:841-859.

Elith J, Graham CH, Anderson RP, Dudik M, Ferrier S, Guisan A, Hijmans RJ, Huettmann F, Leathwick JR, Lehmann A, Li J, Lohmann LG, Loiselle BA, Manion G, Moritz C, Nakamura M, Nakazawa Y, Overton J McC., Peterson AT, Phillips SJ, Richardson K, Scachetti-Pereira R, Schapire RE, Soberon J, Williams S, Wisz MS, and Zimmermann NE. 2006. Novel methods improve prediction of species' distributions from occurrence data. Ecography 29:129-151.

Elith J, Kearney M, and Phillips S. 2010. The art of modelling range-shifting species. Methods in Ecology and Evolution 1:330-342.

Elith J, Phillips SJ, Hastie T, Dudik M, Chee YE, and Yates CJ. 2011. A statistical explanation for 
461

462

463

464

465

466

467

468

469

470

471

472

473

474

475

476

477

478

479

480

481

482

483

484

485

486

487

488

489

490

491

492

493

494

495

496

497

498

499

500

501

502

503

504

505

506

507

508

509

510

511

MaxEnt for ecologists. Diversity and Distributions 17:43-57.

Elmendorf SC, Moore KA. 2008. Use of community-composition data to predict the fecundity and abundance of species. Conservation Biology. 22:1523-1532.

Engelstaedter S, Kohfeld K, Tegen I, and Harrison S. 2003. Controls of dust emissions by vegetation and topographic depressions: An evaluation using dust storm frequency data. Geophysical Research Letters 30. 1294, doi:10.1029/2002GL016471.

ESCAVI. 2003. (Executive Steering Committee for Australian Vegetation Information). Australian Vegetation Attribute Manual: National Vegetation Information System. p 152.

Evans J. 1992. Plantation forestry in the tropics: tree planting for industrial, social, environmental, and agroforestry purposes: Oxford University Press.

Fisher JB, Whittaker RJ, and Malhi Y. 2011. ET come home: potential evapotranspiration in geographical ecology. Global Ecology and Biogeography 20:1-18.

Fitzpatrick MC, Gove AD, Sanders NJ, and Dunn RR. 2008. Climate change, plant migration, and range collapse in a global biodiversity hotspot: the Banksia (Proteaceae) of Western Australia. Global Change Biology 14:1337-1352.

Franklin J, McCullough P, and Gray C. 2000. Terrain Analysis: Principles and Applications: Terrain variables used for predictive mapping of vegetation communities in southern California. Wiley 331:353.

Franklin J. 1998. Predicting the distribution of shrub species in southern California from climate and terrain-derived variables. Journal of Vegetation Science 9:733-748.

Gherardi LA, and Sala OE. 2015. Enhanced precipitation variability decreases grass-and increases shrubproductivity. Proceedings of the National Academy of Sciences 112:12735-12740.

González-Orozco CE, Shawn FW, Knerr N, and Miller J. 2013. A biogeographical regionalization of Australian Acacia species. Journal of Biogeography 40:2156-2166.

Groves RH. 1994. Australian vegetation: Cambridge University Press.

Guisan A, and Rahbek C. 2011. SESAM-a new framework integrating macroecological and species distribution models for predicting spatio-temporal patterns of species assemblages. Journal of Biogeography 38:1433-1444.

Guisan A, and Thuiller W. 2005. Predicting species distribution: offering more than simple habitat models. Ecology Letters 8:993-1009.

Guisan A, and Zimmermann NE. 2000. Predictive habitat distribution models in ecology. Ecological Modelling 135:147-186.

Haque M, Nipperess D, Gallagher R, and Beaumont L. in press. A Legacy of Sampling: Exploring spatial patterns among occurrence records in Australia's Virtual Herbarium. Austral Ecology.

Hefley TJ, Baasch DM, Tyre AJ, and Blankenship EE. 2013. Correction of location errors for presence-only species distribution models. Methods in Ecology and Evolution 5:207-214.

Hibbard K, Archer S, Schimel D, and Valentine D. 2001. Biogeochemical changes accompanying woody plant encroachment in a subtropical savanna. Ecology 82:1999-2011.

Hijmans RJ, Cameron SE, Parra JL, Jones PG, and Jarvis A. 2005. Very high resolution interpolated climate surfaces for global land areas. International journal of climatology 25:1965-1978.

Hortal J, De Marco Jr P, Santos A, and Diniz-Filho JAF. 2012. Integrating biogeographical processes and local community assembly. Journal of Biogeography 39:627-628.

Hosseini S, Kappas M, Chahouki MZ, Gerold G, Erasmi S, and Emam AR. 2013. Modelling potential habitats for Artemisia sieberi and Artemisia aucheri in Poshtkouh area, central Iran using the maximum entropy model and geostatistics. Ecological informatics 18:61-68.

Hutchinson MF. 1995. Interpolation of mean rainfall using thin plate smoothing splines. International Journal of Geographical Information Systems 9:385-403.

IBRA. 2015. Interim Biogeographic Regionalisation for Australia. SA Department of Environment, Water and Natural Resources. IBRA Subregion Australia Version 7.0 - PED. Bioregional Assessment Source Dataset.

Jackson R, and Caldwell M. 1993. Geostatistical patterns of soil heterogeneity around individual 
512

513

514

515

516

517

518

519

520

521

522

523

524

525

526

527

528

529

530

531

532

533

534

535

536

537

538

539

540

541

542

543

544

545

546

547

548

549

550

551

552

553

554

555

556

557

558

559

560

561

perennial plants. Journal of Ecology 81:683-692.

Jackson SD. 2009. Plant responses to photoperiod. New Phytologist 181:517-531.

Jarvis SC. 1974. Soil Factors Affecting the Distribution of Plant Communities on the Cliffs of Craig Breidden, Montgomeryshire. Journal of Ecology 62:721-733.

Keith DA, Akçakaya HR, Thuiller W, Midgley GF, Pearson RG, Phillips SJ, Regan HM, Araújo MB, Rebelo TG. 2008. Predicting extinction risks under climate change: coupling stochastic population models with dynamic bioclimatic habitat models. Biology Letters. 4:560-3.

Kienast F, Wildi O, and Brzeziecki B. 1998. Potential impacts of climate change on species richness in mountain forests - an ecological risk assessment. Biological Conservation 83:291-305.

Lawler JJ, Lewisb DJ, Nelsonc E, Plantingad AJ, Polaskye S, Withey JC, Helmersg DP, Martinuzzig S, Penningtonh D, and Radeloffg VC. 2014. Projected land-use change impacts on ecosystem services in the United States, PNAS 111:7492-7497.

Lefroy E, Dann P, Wildin J, Wesley-Smith R, and McGowan A. 1992. Trees and shrubs as sources of fodder in Australia. The Role of Trees in Sustainable Agriculture: Springer, 117-139.

Li X, Tan H, He M, Wang X, and Li X. 2009. Patterns of shrub species richness and abundance in relation to environmental factors on the Alxa Plateau: Prerequisites for conserving shrub diversity in extreme arid desert regions. Science in China Series D: Earth Sciences 52:669-680.

Liu C, White M, and Newell G. 2009. Assessing the accuracy of species distribution models more thoroughly. 18th World IMACS / MODSIM Congress. Cairns, Australia: Citeseer. p 4234-4240.

Liu C, White M, and Newell G. 2013. Selecting thresholds for the prediction of species occurrence with presence-only data. Journal of Biogeography 40:778-789.

McDonald GK, Tavakkoli E, Cozzolino D, Banas K, Derrien M, Rengasamy P. 2017. A survey of total and dissolved organic carbon in alkaline soils of southern Australia. Australian Journal of Soil Research DOI: 10.1071/SR16237.

Malajczuk N, McComb A, and Loneragan J. 1975. Phosphorus uptake and growth of mycorrhizal and uninfected seedlings of Eucalyptus calophylla R. Br. Australian Journal of Botany 23:231-238.

Martinson EJ, Eddy ZB, Commerford JL, Blevins E, Rolfsmeier SJ, and McLauchlan KK. 2011. Biogeographic distributions of selected North American grassland plant species. Physical Geography 32:583-602.

Martre P, North GB, Bobich EG, and Nobel PS. 2002. Root deployment and shoot growth for two desert species in response to soil rockiness. American Journal of Botany 89:1933-1939.

Meentemeyer RK, Moody A, Franklin J, 2001. Landscape scale patterns of shrub-species abundance in California chaparral: the role of topographically mediated resource gradients. Plant Ecology. 156:19-41.

Meier ES, Lischke H, Schmatz DR, and Zimmermann NE. 2012. Climate, competition and connectivity affect future migration and ranges of European trees. Global Ecology and Biogeography 21:164178.

Meng T-T, Ni J, and Harrison SP. 2009. Plant morphometric traits and climate gradients in northern China: a meta-analysis using quadrat and flora data. Annals of Botany 104, 1217-1229.

Merow C, Smith MJ, and Silander JA. 2013. A practical guide to MaxEnt for modeling species' distributions: what it does, and why inputs and settings matter. Ecography 36:1058-1069.

Monjardino M, Revell D, and Pannell DJ. 2010. The potential contribution of forage shrubs to economic returns and environmental management in Australian dryland agricultural systems. Agricultural Systems 103:187-197.

Nano CEM and Clarke PJ.2008. Variegated desert vegetation: Covariation of edaphic and fire variables provides a framework for understanding mulga-spinifex coexistence. Austral Ecology 33:848862.

Neher D, Weicht T, Moorhead D, and Sinsabaugh R. 2004. Elevated CO2 alters functional attributes of nematode communities in forest soils. Functional Ecology 18:584-591.

Nix HA. 1986. A biogeographic analysis of Australian elapid snakes. Atlas of elapid snakes of Australia 
562

563

564

565

566

567

568

569

570

571

572

573

574

575

576

577

578

579

580

581

582

583

584

585

586

587

588

589

590

591

592

593

594

595

596

597

598

599

600

601

602

603

604

605

606

607

608

609

610

611

612

7:4-15.

Pearce J, and Ferrier S. 2000. Evaluating the predictive performance of habitat models developed using logistic regression. Ecological Modelling 133:225-245.

Pedley L. 1979. A revision of Acacia Mill. in Queensland. Austrobaileya 1:235-337.

Phillips S, Anderson R, and Schapire R. 2006. Maximum entropy modeling of species geographic distributions. Ecological Modelling 190:231-259.

Phillips SJ, Dudík M, Elith J, Graham CH, Lehmann A, Leathwick J, and Ferrier S. 2009. Sample selection bias and presence-only distribution models: implications for background and pseudo-absence data. Ecological Applications 19:181-197.

Phillips SJ, Dudík M, and Schapire RE. 2004. A maximum entropy approach to species distribution modeling. Proceedings of the twenty-first international conference on Machine learning: ACM. $p$ 83.

Pressland A. 1973. Rainfall partitioning by an arid woodland (Acacia aneura F. Muell.) in south-western Queensland. Australian journal of Botany 21:235-245.

R Development Core Team, 2014. R: A language and environment for statistical computing. R Foundation for Statistical Computing, Vienna, Austria

Raupach M, Briggs P, Haverd V, King E, Paget M, and Trudinger C. 2009. Australian water availability project (AWAP): CSIRO marine and atmospheric research component: final report for phase 3. Centre for Australian weather and climate research (bureau of meteorology and CSIRO) Melbourne, Australia 67.

Raupach M, Briggs P, Haverd V, King E, Paget M, and Trudinger C. 2012. Australian Water Availability Project. CSIRO Marine and Atmospheric Research, Canberra, Australia. http://www.csiro.au/awap.

Reddell P, Bowen GD, and Robson AD. The Effects of Soil Temperature on Plant Growth, Nodulation and Nitrogen Fixation in Casuarina cunninghamiana Miq. 1985. The New Phytologist. 101:441-450.

Reynolds MP. 1999. Residual leaf area as a measure of shrub use. MSc Thesis, Oregon State University.

Sandoval Pérez AL, Camargo-Ricalde SL, Montaño NM, García-Oliva F, Alarcón A, Montaño-Arias SA, and Esperón-Rodríguez M. 2016. Biocrusts, inside and outside resource islands of Mimosa luisana (Leguminosae), improve soil carbon and nitrogen dynamics in a tropical semiarid ecosystem. European Journal of Soil Biology 74:93-103. http://dx.doi.org/10.1016/j.ejsobi.2016.03.006

Sauer TJ, Cambardella CA, and Meek DW. 2006. Spatial variation of soil properties relating to vegetation changes. Plant and soil 280:1-5.

Schlesinger WH, Raikes JA, Hartley AE, and Cross AF. 1996. On the spatial pattern of soil nutrients in desert ecosystems. Ecology 77:364-374.

Smith SD, Monson R, and Anderson JE. 1997. Physiological ecology of North American desert plants. University of Nevada, Berlin, Heidelberg.

Song W-K, Cui Y-J, Tang AM, Ding W-Q, and Tran TD. 2013. Experimental study on water evaporation from sand using environmental chamber. Canadian Geotechnical Journal 51:115-128.

Specht R. 1966. The growth and distribution of mallee-broombush (Eucalyptus incrassata-Melaleuca uncinata association) and heath vegetation near Dark Island Soak, Ninety-Mile Plain, South Australia. Australian journal of Botany 14:361-371.

Stanton JC, Pearson RG, Horning N, Ersts P, and Reşit Akçakaya H. 2012. Combining static and dynamic variables in species distribution models under climate change. Methods in Ecology and Evolution 3:349-357.

Summers DM, Bryan BA, Crossman ND, and Meyer WS. 2012. Species vulnerability to climate change: impacts on spatial conservation priorities and species representation. Global Change Biology 18:2335-2348.

Taylor S, and Kumar L. 2013. Potential distribution of an invasive species under climate change scenarios 
613

614

615

616

617

618

619

620

621

622

623

624

625

626

627

628

629

630

631

632

633

634

635

636

637

638

639

640

641

642

643

644

645

646

647

648

649

650

651

652

653

654

655

656

657

658 using CLIMEX and soil drainage: A case study of Lantana camara L. in Queensland, Australia. Journal of environmental management 114:414-422.

Titeux N, Henle K, Mihoub JB, Regos A, Geijzendorffer IR, Cramer W, Verburg PH, and Brotons L. 2016. Biodiversity scenarios neglect future land-use changes. Global Change Biology 22:25052515.

Vanderwal J, Beaumont L, Zimmermann N, and Lorch P. 2011. Package 'climates': methods for working with weather and climate. Available from $w w w$ rforge.

Viscarra Rossel R, Chen C, Grundy M, Searle R, Clifford D, and Odgers N. 2014a. Soil and Landscape Grid National Soil Attribute Maps-Total Phosphorus (3" resolution)-Release 1. v4. CSIRO Data Collection 1:08.

Viscarra Rossel R, Chen C, Grundy M, Searle R, Clifford D, Odgers N, Holmes K, Griffin T, Liddicoat C, and Kidd D. 2014b. Soil and Landscape Grid National Soil Attribute Maps - Bulk Density Whole Earth (3" resolution). Release 1. v4. CSIRO. Data Collection. http://doi.org/10.4225/08/546EE212B0048.

Viscarra Rossel R, Chen C, Grundy M, Searle R, Clifford D, Odgers N, Holmes K, Griffin T, Liddicoat C, and Kidd D. 2014c. Soil and Landscape Grid National Soil Attribute Maps - Organic Carbon (3" resolution) Release 1. v1. CSIRO. Data Collection. http://doi.org/10.4225/08/547523BB0801A.

Viscarra Rossel R, Chen C, Grundy M, Searle R, Clifford D, Odgers N, Holmes K, Griffin T, Liddicoat C, and Kidd D. 2014d. Soil and Landscape Grid National Soil Attribute Maps - pH - CaCl2 (3" resolution). Release 1. v2. CSIRO. Data Collection. http://doi.org/10.4225/08/546F17EC6AB6E.

Warren DL, Glor RE, and Turelli M. 2008. Environmental niche equivalency versus conservatism: quantitative approaches to niche evolution. Evolution 62:2868-2883.

Westman WE. 1991. Measuring realized niche spaces: climatic response of chaparral and coastal sage scrub. Ecology 72:1678-1684.

Williams KJ, Belbin L, Austin MP, Stein JL, and Ferrier S. 2012. Which environmental variables should I use in my biodiversity model? International Journal of Geographical Information Science 26:2009-2047.

Woodward FI. 1987. Climate and plant distribution: Cambridge University Press.

Xin-Rong L. 2001. Study on shrub community diversity of Ordos Plateau, Inner Mongolia, northern China. Journal of Arid Environments 47:271-279.

$\mathrm{Xu}$ T, and Hutchinson MF. 2013. New developments and applications in the ANUCLIM spatial climatic and bioclimatic modelling package. Environmental modelling \& software 40:267-279.

Xu Z, Ward S, Chen C, Blumfield T, Prasolova N, and Liu J. 2008. Soil carbon and nutrient pools, microbial properties and gross nitrogen transformations in adjacent natural forest and hoop pine plantations of subtropical Australia. Journal of Soils and Sediments 8:99-105.

Yashiro Y, Shizu Y, Hirota M, Shimono A, and Ohtsuka T. 2010. The role of shrub (Potentilla fruticosa) on ecosystem CO2 fluxes in an alpine shrub meadow. Journal of Plant Ecology 3:89-97.

Zeng X, Zeng X, and Barlage M. 2008. Growing temperate shrubs over arid and semiarid regions in the Community Land Model-Dynamic Global Vegetation Model. Global Biogeochemical Cycles 22.

Zhou Y, Pei Z, Su J, Zhang J, Zheng Y, Ni J, Xiao C, and Wang R. 2012. Comparing soil organic carbon dynamics in perennial grasses and shrubs in a saline-alkaline arid region, northwestern China. PloS One 7:e42927.

Zinke PJ. 1962. The pattern of influence of individual forest trees on soil properties. Ecology 43:130-133. 
659 Tables

660 Table 1. Distribution changes in shrubs suitable habitats using the models of climate only variables 661 vs. climate with-soil-variables.

662 The projected area $\left(\mathrm{km}^{2}\right)$ of suitable habitat for 29 Australian shrub species, based on models using climate663 only variables $\left(V_{C}\right)$, and using climate-with-soil variables $\left(V_{C+S}\right)$. Also shown the percentage of $V_{C}$ habitat 664 that is also suitable according to $\mathrm{V}_{\mathrm{C}+\mathrm{S}}$ models (Overlap), the percentage of $\mathrm{V}_{\mathrm{C}+\mathrm{S}}$ habitat that is not suitable 665 in the corresponding $\mathrm{V}_{\mathrm{C}}$ model (Gain), and the percentage of $\mathrm{V}_{\mathrm{C}}$ habitat that is not suitable in the 666 corresponding $\mathrm{V}_{\mathrm{C}+\mathrm{S}}$ model (Loss).

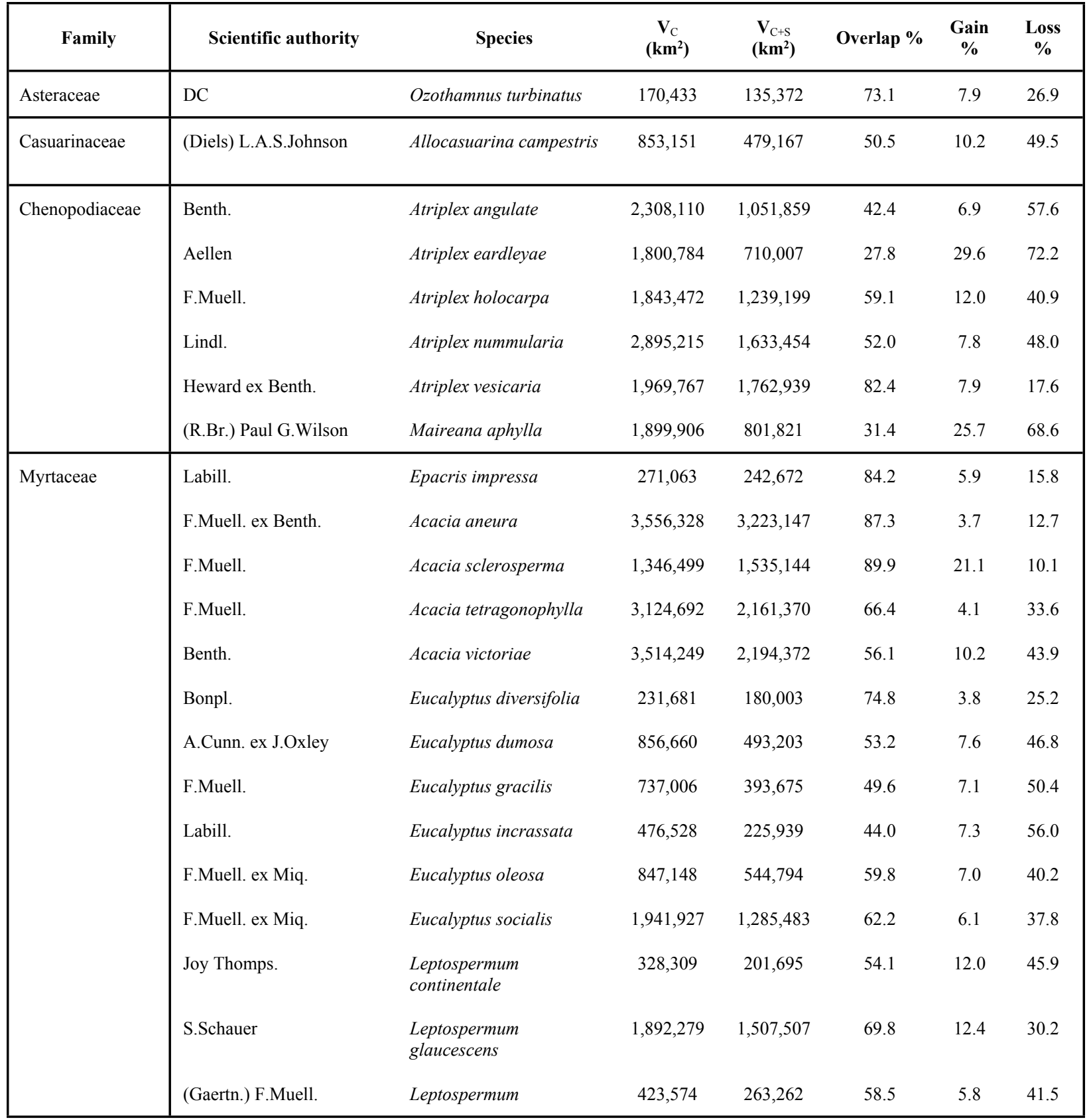




\begin{tabular}{|c|c|c|c|c|c|c|c|}
\hline & (Sol. ex Ait.) Sm. & $\begin{array}{l}\text { laevigatum } \\
\text { Leptospermum } \\
\text { lanigerum }\end{array}$ & 179,713 & 141,520 & 76.2 & 3.3 & 23.8 \\
\hline & J.R.Forst. \& G.Forst. & $\begin{array}{l}\text { Leptospermum } \\
\text { scoparium }\end{array}$ & 73,399 & 72,442 & 95.0 & 3.7 & 5.0 \\
\hline & Sm. & Melaleuca ericifolia & 340,373 & 234,349 & 60.0 & 12.9 & 40.0 \\
\hline & Labill. & Melaleuca squamea & 91,872 & 100,253 & 94.0 & 13.9 & 6.0 \\
\hline & Donn. ex Sm. & Melaleuca squarrosa & 177,074 & 150,365 & 78.5 & 7.5 & 21.5 \\
\hline Sapindaceae & $\begin{array}{l}\text { (F.Muell.) F.Muell. ex } \\
\text { Benth. }\end{array}$ & Atalaya hemiglauca & $5,463,020$ & $3,736,940$ & 65.6 & 4.0 & 34.4 \\
\hline Scrophulariaceae & F.Muell. & Eremophila freelingii & $1,663,875$ & 647,367 & 31.4 & 19.2 & 68.6 \\
\hline
\end{tabular}

667

668

669

670

671

672

673

674

675

676

677

678 
679 Table 2. The environmental predictor sets used in the different models.

680 Alternative predictor sets used in models $\left(\mathrm{V}_{\mathrm{C}}=\right.$ climate variables only; $\mathrm{V}_{\mathrm{C}+\mathrm{S}}=$ climate and soil variables;

$681 \quad \mathrm{~V}_{\mathrm{S}}=$ soil variables only).

\begin{tabular}{|c|l|c|c|c|}
\hline Abbreviation & Environment Variable & $\mathbf{V}_{\mathbf{C}}$ & $\mathbf{V}_{\mathrm{C}+\mathrm{S}}$ & $\mathbf{V}_{\mathbf{S}}$ \\
\hline $\mathrm{T}$ & Annual Mean Temperature & $\bullet$ & $\bullet$ & \\
TMwarm & $\begin{array}{l}\text { Maximum Temperature of Warmest } \\
\text { Month }\end{array}$ & $\bullet$ & $\bullet$ & \\
$\mathrm{P}$ & Mean Annual Precipitation & $\bullet$ & $\bullet$ & \\
PQwarm & Precipitation of Warmest Quarter & $\bullet$ & $\bullet$ & \\
PQcold & Precipitation of Coldest Quarter & $\bullet$ & $\bullet$ & \\
BD & Bulk soil density (g/cm $\left.{ }^{3}\right)$ & & $\bullet$ & $\bullet$ \\
CLAY & Clay content percentage & & $\bullet$ & $\bullet$ \\
pH & pH CaCl I $_{2}$ & & $\bullet$ & $\bullet$ \\
OC & Organic carbon percentage & & $\bullet$ & $\bullet$ \\
\hline
\end{tabular}

682

683 
Table 3. Percent contribution of environmental variables used in the different models.

Percent contribution of environmental variables used in the climate-only predictor set $\left(\mathrm{V}_{\mathrm{C}}\right)$, in the climate-with-soil set $\left(\mathrm{V}_{\mathrm{C}+\mathrm{S}}\right)$, and in the soil-only predictor set $\left(\mathrm{V}_{\mathrm{S}}\right)$ to model 29 Australian shrub species. Mean Annual Temperature $(\mathrm{T})$, Maximum Temperature of the Warmest Month (TMwarm), Mean Annual Precipitation (P), Precipitation of the Warmest Quarter (PQwarm), Precipitation of the Coldest Quarter (PQcold), bulk density (BD), clay content percentage (CLAY), $\mathrm{pH} \mathrm{CaCl}_{2}(\mathrm{pH})$, and organic carbon (OC). For each species and predictor set, the highest value is shown in bold. For family names of species, see Table 2.

\begin{tabular}{|c|c|c|c|c|c|c|c|c|c|c|c|c|c|c|c|c|c|c|}
\hline \multirow[b]{2}{*}{ Species } & \multicolumn{5}{|c|}{$\mathrm{V}_{\mathrm{C}}$} & \multicolumn{9}{|c|}{$\mathrm{V}_{\mathrm{C}+\mathrm{S}}$} & \multicolumn{4}{|c|}{$\mathrm{V}_{\mathrm{S}}$} \\
\hline & $\mathrm{P}$ & $\mathrm{T}$ & TMwarm & PQcold & PQwarm & $\mathrm{P}$ & $\mathrm{T}$ & TMwarm & PQcold & PQwarm & $\mathrm{BD}$ & CLAY & $\mathrm{pH}$ & $\mathrm{OC}$ & $\mathrm{BD}$ & CLAY & $\mathrm{pH}$ & $\mathrm{OC}$ \\
\hline Ozothamnus turbinatus & $<0.01$ & 35.3 & 42.9 & 14.9 & 6.9 & $<0.01$ & 28.3 & 46.8 & 6.7 & 2.5 & 1.4 & 4.4 & 8.6 & 1.3 & 62.8 & 12.2 & 19.8 & 5.2 \\
\hline Allocasuarina campestris & 6.7 & 11.0 & 25.3 & 28.1 & 28.9 & 6.4 & 11.9 & 19.0 & 17.2 & 28.7 & 3.4 & 2.7 & 2.4 & 8.2 & 8.6 & 16.1 & 0.9 & 74.3 \\
\hline Atriplex angulata & 45.6 & 45.9 & 5.1 & 0.9 & 2.6 & 37.2 & 33.5 & 6.4 & 0.5 & 1.5 & 7.3 & 6.8 & 6.5 & 0.5 & 24.0 & 20.4 & 37.6 & 18.1 \\
\hline Atriplex eardleyae & 24.3 & 25.1 & 23.5 & 19.8 & 7.3 & 5.9 & 7.5 & 6.5 & 2.0 & 2.3 & 5.0 & 7.2 & 62.9 & 0.7 & 5.9 & 11.2 & 80.5 & 2.4 \\
\hline Atriplex holocarpa & 47.0 & 46.8 & 2.4 & 3.3 & 0.4 & 34.8 & 32.3 & 9.0 & 1.7 & 1.7 & 3.6 & 2.3 & 12.6 & 2.1 & 27.9 & 2.6 & 42.3 & 27.2 \\
\hline Atriplex nummularia & 41.1 & 7.6 & 41.1 & 6.8 & 3.4 & 28.8 & 4.8 & 1.3 & 2.5 & 6.8 & 33.9 & 14.2 & 7.2 & 0.4 & 15.8 & 10.0 & 57.7 & 16.5 \\
\hline Atriplex vesicaria & 36.9 & 1.6 & 49.8 & 3.7 & 7.9 & 29.5 & 2.1 & 32.2 & 1.7 & 9.2 & 9.0 & 2.0 & 14.0 & 0.2 & 8.6 & 7.7 & 77.4 & 6.4 \\
\hline Maireana aphylla & 37.7 & 52.0 & 5.9 & 1.2 & 3.1 & 22.5 & 23.8 & 1.8 & 2.4 & 3.3 & 15.5 & 29.0 & 1.6 & 0.2 & 23.1 & 33.4 & 35.6 & 7.9 \\
\hline Epacris impressa & 1.5 & 2.5 & 85.8 & 2.9 & 7.3 & 0.9 & 3.2 & 83.0 & 3.2 & 7.4 & 0.5 & 0.4 & 0.4 & 1.0 & 58.9 & 4.2 & 3.0 & 33.9 \\
\hline Acacia aneura & 30.9 & 15.2 & 29.6 & 21.5 & 2.8 & 27.8 & 10.8 & 4.2 & 7.2 & 1.0 & 26.0 & 4.8 & 10.2 & 8.1 & 18.8 & 18.9 & 26.0 & 36.4 \\
\hline Acacia sclerosperma & 27.7 & 39.3 & 12.1 & 8.2 & 12.7 & 18.4 & 40.0 & 10.1 & 10.3 & 2.6 & 1.5 & 1.5 & 15.4 & 0.3 & 18.6 & 21.1 & 36.6 & 23.7 \\
\hline Acacia tetragonophylla & 70.9 & 6.1 & 2.7 & 3.0 & 17.4 & 26.6 & 6.9 & 4.0 & 0.7 & 10.1 & 13.6 & 4.7 & 22.6 & 10.7 & 34.7 & 30.9 & 10.8 & 23.6 \\
\hline Acacia victoriae & 33.4 & 15.8 & 30.4 & 19.4 & 1.0 & 9.5 & 7.6 & 7.2 & 3.6 & 2.7 & 12.4 & 4.0 & 44.7 & 8.3 & 17.2 & 7.3 & 59.7 & 15.7 \\
\hline
\end{tabular}




\begin{tabular}{|c|c|c|c|c|c|c|c|c|c|c|c|c|c|c|c|c|c|c|}
\hline Eucalyptus diversifolia & 0.3 & 25.8 & 24.3 & 23.7 & 25.9 & 0.3 & 2.9 & 17.8 & 23.9 & 19.4 & 7.7 & 0.8 & 25.7 & 1.4 & 9.0 & 14.3 & 50.9 & 25.8 \\
\hline Eucalyptus dumosa & 8.2 & 35.4 & 3.4 & 20.2 & 32.9 & 2.2 & 16.1 & 3.5 & 7.9 & 10.2 & 2.6 & 18.0 & 38.6 & 0.9 & 4.4 & 30.7 & 63.9 & 1.0 \\
\hline Eucalyptus gracilis & 15.5 & 20.1 & 37.9 & 7.9 & 18.6 & 1.9 & 4.5 & 4.2 & 4.4 & 3.7 & 0.2 & 8.3 & 72.3 & 0.5 & 0.3 & 12.6 & 86.7 & 0.5 \\
\hline Eucalyptus incrassata & 3.5 & 25.4 & 33.0 & 15.4 & 22.8 & 0.2 & 18.0 & 10.1 & 2.9 & 4.6 & 10.5 & 17.3 & 35.7 & 0.8 & 16.5 & 25.2 & 56.0 & 2.2 \\
\hline Eucalyptus oleosa & 14.2 & 15.3 & 43.4 & 4.2 & 23.0 & 1.7 & 1.7 & 11.3 & 2.8 & 6.3 & 2.5 & 9.2 & 64.3 & 0.2 & 0.1 & 19.1 & 80.5 & 0.3 \\
\hline Eucalyptus socialis & 8.4 & 34.4 & 18.8 & 11.5 & 27.0 & 1.7 & 10.8 & 4.1 & 4.6 & 3.7 & 2.8 & 13.8 & $\mathbf{5 8 . 0}$ & 0.4 & 2.9 & 19.6 & 76.6 & 0.9 \\
\hline $\begin{array}{l}\text { Leptospermum } \\
\text { continentale }\end{array}$ & 4.1 & 10.4 & 62.5 & 19.0 & 3.9 & 5.2 & 3.6 & 46.2 & 16.6 & 1.8 & 11.6 & 3.1 & 10.0 & 2.0 & 1.7 & 39.2 & 25.5 & 33.7 \\
\hline $\begin{array}{l}\text { Leptospermum } \\
\text { glaucescens }\end{array}$ & 2.9 & 42.4 & 13.4 & 38.7 & 2.6 & 7.3 & 39.6 & 4.4 & 19.7 & 2.1 & 7.2 & 4.4 & 11.1 & 4.2 & 27.7 & 27.2 & 37.4 & 7.6 \\
\hline $\begin{array}{l}\text { Leptospermum } \\
\text { laevigatum }\end{array}$ & 9.8 & 31.3 & 28.0 & 26.8 & 4.1 & 1.4 & 26.1 & 23.1 & 20.4 & 1.7 & 0.9 & 12.1 & 8.9 & 5.5 & 14.3 & 19.8 & 38.4 & 27.5 \\
\hline Leptospermum lanigerum & 0.7 & 1.4 & 92.2 & 2.7 & 3.0 & 2.2 & 1.4 & 90.7 & 1.2 & 2.5 & 0.5 & 0.3 & 0.1 & 1.1 & 69.7 & 10.0 & 2.2 & 18.2 \\
\hline Leptospermum scoparium & 0.7 & 12.6 & 83.6 & 1.1 & 2.0 & 0.5 & 12.7 & 80.1 & 1.5 & 2.6 & 0.1 & 1.8 & 0.6 & 0.2 & 35.9 & 30.6 & 17.9 & 15.6 \\
\hline Melaleuca ericifolia & 5.5 & 24.1 & 58.0 & 1.1 & 11.3 & 1.1 & 20.4 & 51.0 & 1.8 & 7.8 & 2.8 & 4.7 & 5.8 & 4.4 & 32.1 & 3.0 & 46.1 & 18.8 \\
\hline Melaleuca squamea & 3.9 & 5.4 & 83.2 & 6.6 & 0.9 & 0.9 & 8.0 & 73.3 & 7.5 & 2.2 & 2.5 & 1.4 & 1.9 & 2.1 & 30.7 & 20.5 & 7.6 & 41.2 \\
\hline Melaleuca squarrosa & 3.1 & 17.6 & 65.9 & 12.3 & 1.0 & 2.7 & 20.9 & 60.7 & 7.5 & 2.2 & 1.7 & 0.3 & 3.3 & 0.8 & 43.1 & 15.3 & 29.1 & 12.4 \\
\hline Atalaya hemiglauca & 18.4 & 10.2 & 66.5 & 4.8 & 0.1 & 12.1 & 16.3 & 34.6 & 3.7 & 0.3 & 3.9 & 5.0 & 22.0 & 2.1 & 42.8 & 14.9 & 2.4 & 39.8 \\
\hline Eremophila freelingii & 9.0 & 59.6 & 4.9 & 13.0 & 13.5 & 3.0 & 38.1 & 5.0 & 2.4 & 6.2 & 20.3 & 3.7 & 3.4 & 18.0 & 41.2 & 20.2 & 20.5 & 18.1 \\
\hline
\end{tabular}


692 Figures
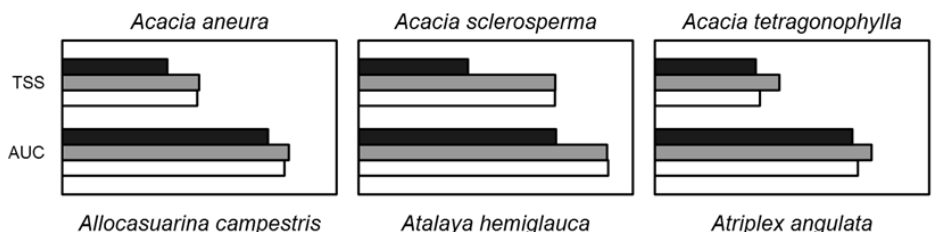

Atalaya hemiglauca
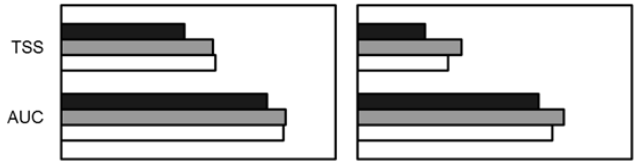

Atriplex angulata

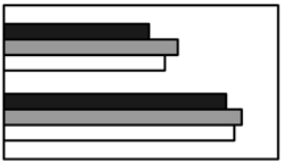

Atriplex holocarpa

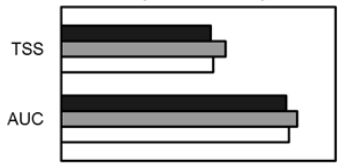

Atriplex nummularia

Atriplex vesicaria

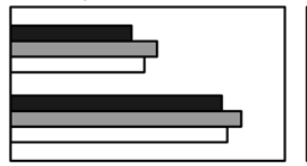

Eremophila freelingii

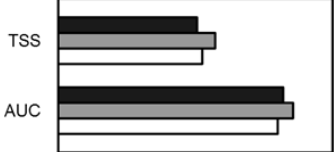

Eucalyptus diversifolia

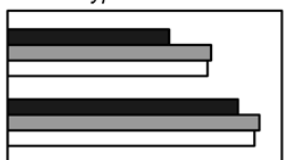

Eucalyptus incrassata

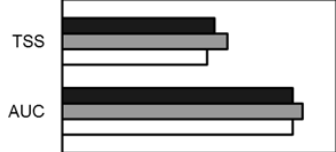

Eucalyptus oleosa

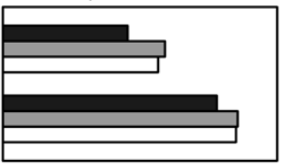

Eucalyptus dumosa

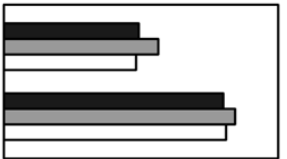

Eucalyptus socialis

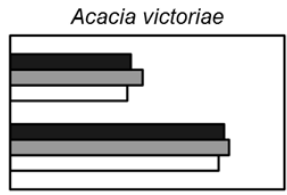

Atriplex eardleyae

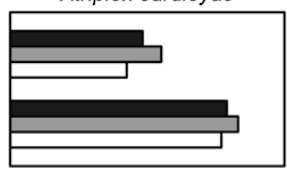

Epacris impressa

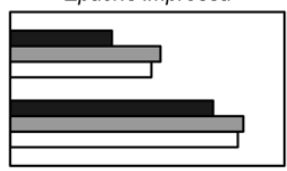

Eucalyptus gracilis

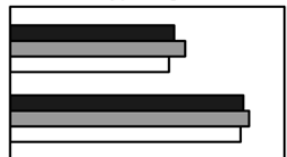

Leptospermum continentale
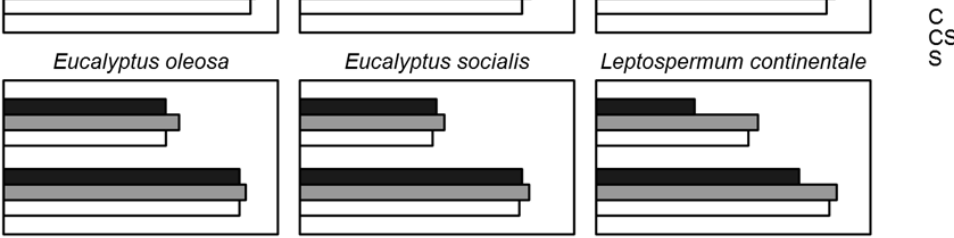

ç

693

Leptospermum laevigatum

Leptospermum lanigerum

Leptospermum scoparium

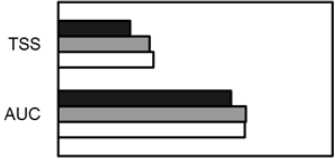

Maireana aphylla
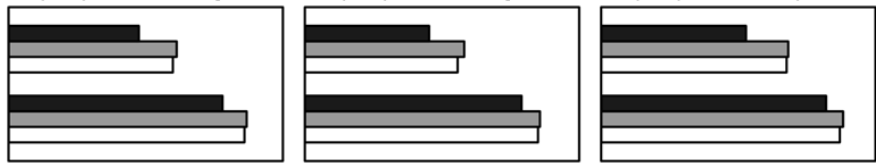

Melaleuca squamea

Melaleuca squarrosa

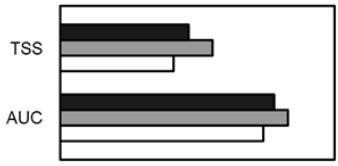

Melaleuca ericifolia
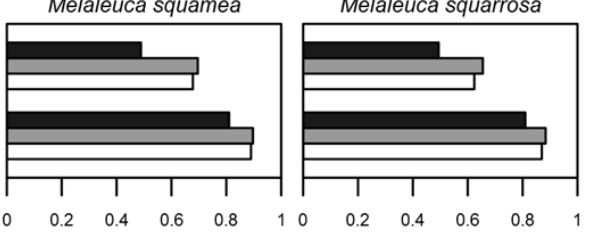

Ozothamnus turbinatus
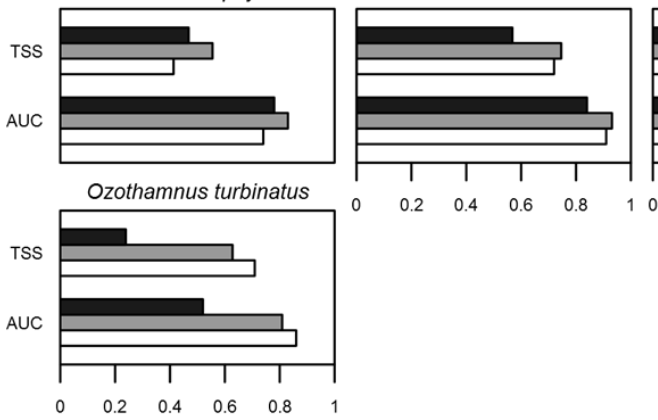

$\begin{array}{llll}0.2 & 0.4 & 0.6 & 0.8\end{array}$

694 Figure 1. Mean values of the true skill statistic (TSS) and the area under the receiver-operating

695 characteristic curve (AUC) of different used models.

696 Values of mean TSS and AUC for 29 shrub species from Australia for which suitable habitat was modelled

697 (with Maxent) using three sets of predictor variables: climate-only $\left(\mathrm{V}_{\mathrm{C}}\right)$, climate-with-soil

$698\left(\mathrm{~V}_{\mathrm{C}+\mathrm{S}}\right)$, and soil-only $\left(\mathrm{V}_{\mathrm{S}}\right)$. 


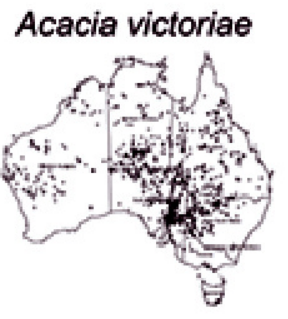

(A) Climate

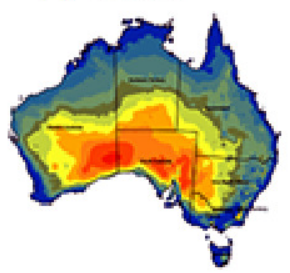

Atriplex eardleyae
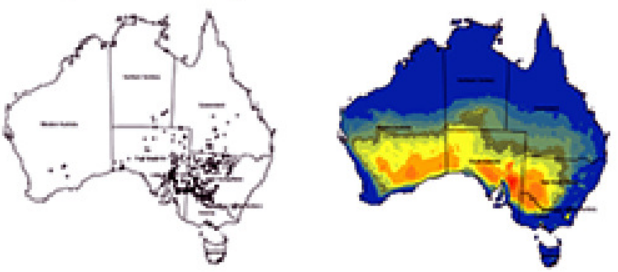

Eucalyptus gracilis
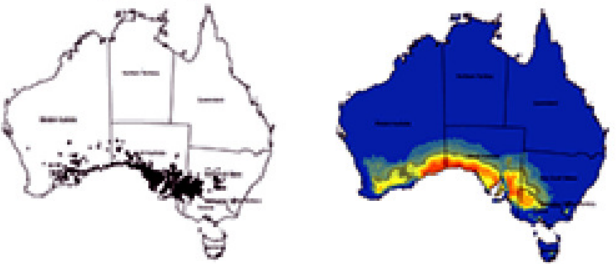

Leptospermum continentale
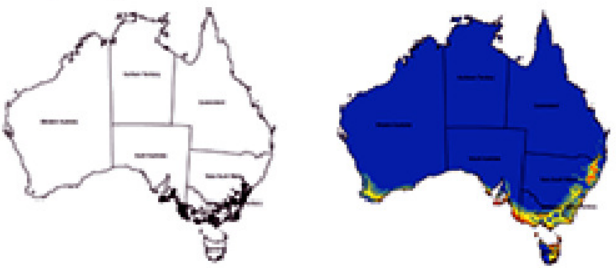

Maireana aphylla
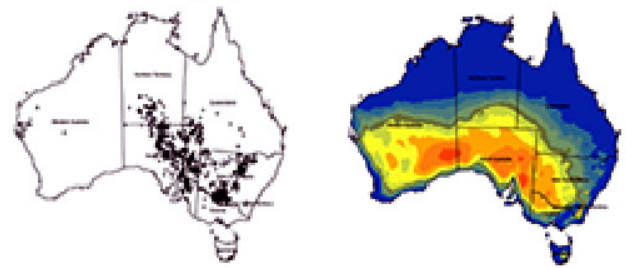
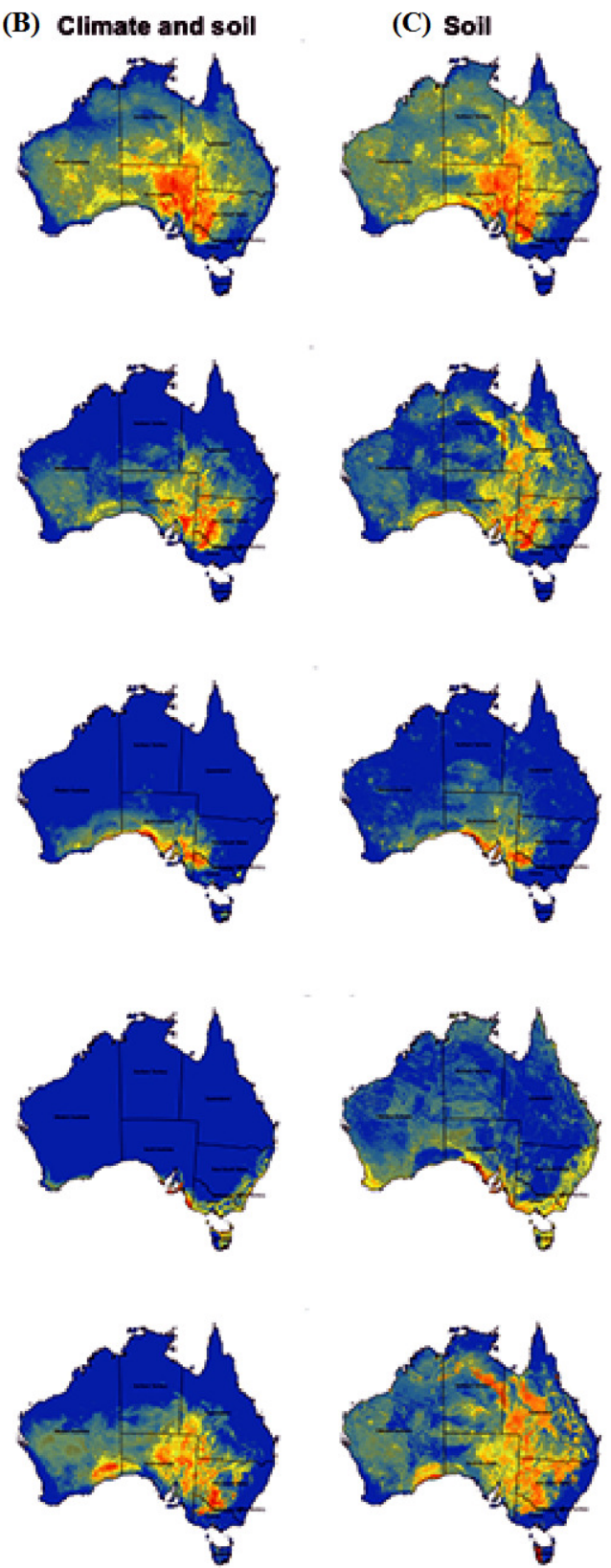

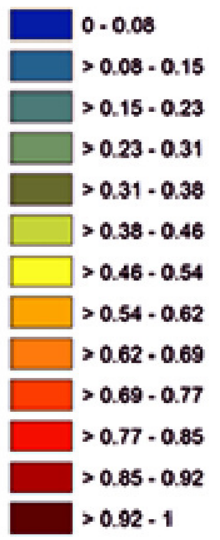

699

Figure 2. Habitat prediction maps of some species used in different models.

Maxent predictions of habitat suitability for five Australian shrub species: Acacia victoriae, Atriplex eardleyae, Eucalyptus gracilis, Leptospermum continentale, and Maireana aphylla. Occurrence records for each species are shown in maps in the first column. Habitat suitability was modelled with different sets of environmental predictors: Climate-only $\left(\mathrm{V}_{\mathrm{C}}\right)$ (column $\left.\mathrm{A}\right)$, Climate-with-soil $\left(\mathrm{V}_{\mathrm{C}+\mathrm{S}}\right)$ (column $\mathrm{B}$ ), and Soilonly $\left(\mathrm{V}_{\mathrm{S}}\right)$ (column $\mathrm{C}$ ). Warmer colours (red) show areas predicted to have higher suitability. Bright blue represents unsuitable areas. 


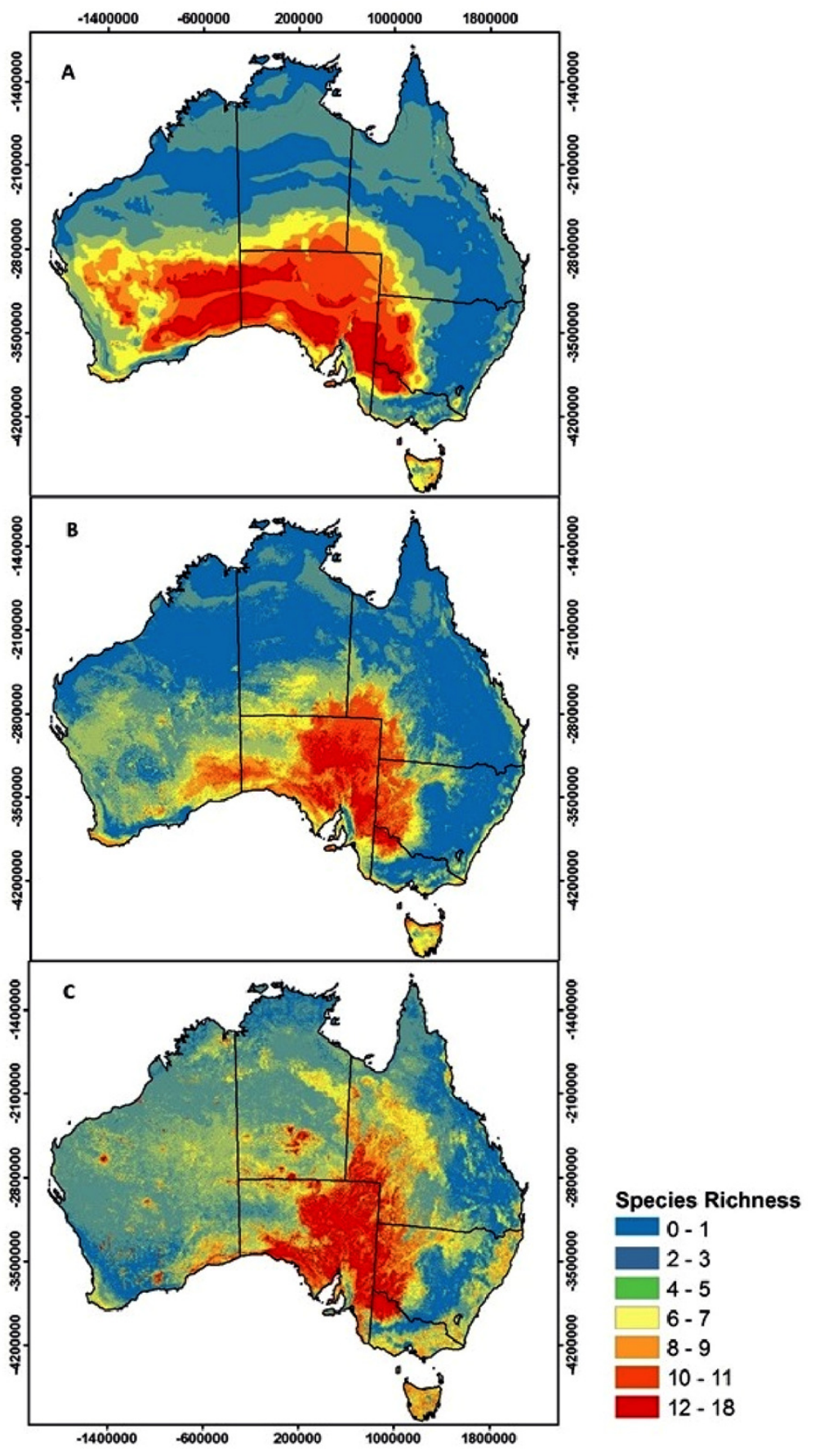

Figure 3. Species richness based in different used models.

710 Maps of potential richness of 29 Australian shrub species, based on Maxent models calibrated with (A)

711 climate variables only $\left(\mathrm{V}_{\mathrm{C}}\right)$, $(\mathrm{B})$ climate and soil variables $\left(\mathrm{V}_{\mathrm{C}+\mathrm{S}}\right)$, and $(\mathrm{C})$ soil variables only $\left(\mathrm{V}_{\mathrm{S}}\right)$. Warmer

712 colours (red) show areas with higher potential richness. 